\title{
A novel kinesin involved in flagellum attachment and positioning in Trypanosoma brucei
}

\author{
S Luiggi ${ }^{1}$, A Raïa ${ }^{1}$, L Petit ${ }^{1}$, T Blisnick ${ }^{2}$, S Perrot ${ }^{2}$, L Pao ${ }^{1}$, P Bastin² ${ }^{2}$ P Grellier ${ }^{1}$, L Kohl ${ }^{1 *}$ \\ From Cilia 2014 - Second International Conference \\ Paris, France. 18-21 November 2014
}

\section{Objective}

Kinesins are motor proteins that transport cargo along microtubules using ATP and fulfil important roles in cilia and flagella. KIN5 is an orphan kinesin, i.e. it does not belong to any of the known kinesin families, and it is found only in trypanosomatids.

\section{Methods}

The function of this protein has been investigated by inducible RNA interference (RNAi) followed by phenotypic characterisation, in the protist Trypanosoma bruce $i$, which possesses a single attached flagellum. Its localisation was determined by expressing a hybrid YFP:: KIN5 protein.

\section{Results}

In procyclic cells KIN5 is localised in the flagellum (probably the axoneme), with a strong fluorescent signal at the distal tip. Depletion of KIN5 results in cells with a mispositioned and partially detached flagellum. The flagellum of the cells is still beating, but the cells are unable to swim. Nevertheless they divide normally indicating that they have adapted to the partially detached flagellum, probably by modifications of the intracellular organisation. Preliminary data indicate that the filament of the Flagellum Attachment Zone is smaller in length in cells depleted of KIN5.

\section{Conclusion}

KIN5 is a flagellar kinesin involved flagellum positioning/attachment, which is not essential for cell survival in procyclic cells in culture. We hypothesise that the cells have adapted their intracellular organisation to allow

\footnotetext{
'Biodiversity and Adaptation of Eukaryotic Microorganisms to their Environment, UMR7245 MNHN/CNRS, National Museum of Natural History, Paris, France

Full list of author information is available at the end of the article
}

replication and cell division. We now investigate the relationship between KIN5 and other proteins known to be involved in flagellum attachment.

\section{Authors' details \\ 'Biodiversity and Adaptation of Eukaryotic Microorganisms to their Environment, UMR7245 MNHN/CNRS, National Museum of Natural History, Paris, France. ${ }^{2}$ Trypanosome Cell Biology Unit, Pasteur Institute, Paris, France. \\ Published: 13 July 2015 \\ doi:10.1186/2046-2530-4-S1-P44 \\ Cite this article as: Luiggi et al:: A novel kinesin involved in flagellum attachment and positioning in Trypanosoma brucei. Cilia 2015 4(Suppl 1): P44.}

Submit your next manuscript to BioMed Central and take full advantage of:

- Convenient online submission

- Thorough peer review

- No space constraints or color figure charges

- Immediate publication on acceptance

- Inclusion in PubMed, CAS, Scopus and Google Scholar

- Research which is freely available for redistribution

Submit your manuscript at www.biomedcentral.com/submit
() Biomed Central 